\title{
Changes in Heavy Metal Accumulation Depending on Traffic Density in Some Landscape Plants
}

\author{
Aydin Turkyilmaz ${ }^{1}$, Hakan Sevik ${ }^{1}$, Mehmet Cetin ${ }^{2 *}$, Elnaji A. Ahmaida Saleh ${ }^{3}$ \\ ${ }^{1}$ Kastamonu University, Faculty of Engineering and Architecture, Department of Environmental Engineering, \\ Kastamonu, Turkey \\ ${ }^{2}$ Kastamonu University, Faculty of Engineering and Architecture, Department of Landscape Architecture, \\ Kastamonu, Turkey \\ ${ }^{3}$ Kastamonu University, Institute of Science, Program of Forest Engineering, Kastamonu, Turkey
}

Received: 24 September 2017

Accepted: 14 October 2017

\begin{abstract}
Air pollution is among the major problems stemming from modern urban life. Millions of people worldwide die from air pollution every year. Especially heavy metals have great importance among these pollutants. Because heavy metals can stay in nature for a long time without deterioration, and their concentration in the environment is constantly increasing. They also tend to bioaccumulate. Many heavy metals arise from exhaust gases, car wheels, vehicles, and vehicle corrosion in cities. Determining heavy metal concentrations in plants is important both for determining the ability of plants to remove heavy metals from the air, and thus to be used as a means of increasing air quality, as well as for monitoring air quality. The purpose of this study is to determine the variation of different heavy metal concentrations, depending on the traffic density, in some landscape plants sampled from areas with different levels of traffic density. Our results show that heavy metal accumulation differs according to both plant species and traffic density. In traffic-dense areas we measured the greatest amounts of $\mathrm{Cu}, \mathrm{Ni}$, and $\mathrm{Fe}$ in Prunus cerasifera; of $\mathrm{Ca}, \mathrm{Mg}$, and $\mathrm{Mn}$ in Ailanthus altissima; of $\mathrm{Cr}$ and $\mathrm{Zn}$ in Elaeagnus angustifolia; and of $\mathrm{Pb}$ and $\mathrm{Cd}$ in Tilia tomentosa.
\end{abstract}

Keywords: heavy metal, traffic density, plants

\section{Introduction}

Millions of people worldwide die from air pollution every year. Because of the intensification of air pollution in urban centers, it poses a great risk - especially for people with various health problems [1-8]. Heavy metals hold a special place among the components of the air pollution. They cannot be destroyed or degraded in nature. They also tend to bioaccumulate in organisms. Thus, determining heavy metal concentration is of paramount importance for the identification of risk areas and levels [9]. A great volume of research has proven the significant effects of atmospheric heavy metal pollution on human health. A recent study has revealed that in 1952, 4,000 people died from heavy metal-induced damage to respiratory systems and reported high levels of heavy metals in their lungs, including $\mathrm{Pb}, \mathrm{Zn}$, and $\mathrm{Fe}$ [10].

*e-mail: mehmet.cetin@temple.edu 
Plants are often used as biomonitors in monitoring heavy metal concentrations. The species used as biomonitors of traffic-induced air pollution include Aesculus hippocastanum, Betula pendula, Platanus orientalis, Fraxinus excelsior, Tilia tomentosa, and Elaeagnus angustifolia [11-14].

Plants used as biomonitors, especially in urban centers with heavy traffic, have also several other benefits such as adding an aesthetic value to their space [15], producing a positive effect on human psychology [16-20], preventing erosion, reducing wind speed and rain rate to allow rainwater to penetrate the soil, providing food and shelter to animals, and performing crucial functions within the ecological system [20-22].

In addition to such functions, plants reduce all kinds of air pollution [15, 21, 23-26]. However, not all plants have the same effect on the removal of heavy metals from the air. Previous studies have shown that different plants have different levels of potential for accumulating different heavy metals. Thus, the effective use of plants both as biomonitors and for the removal of heavy metals from the air is achieved only by determining the heavy metals that different plants tend to accumulate in their bodies.

The purpose of this study is to determine the variation of different heavy metal concentrations, depending on the traffic density, in some landscape plants sampled from areas with different levels of traffic density.

\section{Material and Methods}

Our study was carried out on materials collected from the city center of Ankara. The samples were taken from Tilia tomentosa, Elaeagnus angustifolia, Prunus, and Ailanthus altissima that are frequently used in landscaping. As the leaf samples were collected at the end of the vegetation season, heavy metal accumulation in the leaves occurred in a one-year vegetation cycle. At the end of the vegetation season, the leaves were collected from areas with dense traffic (dense), less dense traffic (less dense), and no vehicle access within a radius of at least $50 \mathrm{~m}$ (no traffic). Leaf specimens used in the work are collected from trees determined according to the traffic density at the end of the vegetation season. Approximately one $\mathrm{kg}$ of leaf ornate is collected and brought to the laboratories in open boxes. The leaves classified in the laboratory were first room-dried for 15 days. From the air-dried samples, 150-200 gr were taken and left in a drying oven at $50^{\circ} \mathrm{C}$ for another 15 days. For analysis, $2 \mathrm{~g}$ dry leaf samples were used for each repetition.

The leaves classified in the laboratory were first room-dried for 15 days and then left in a drying oven at $50^{\circ} \mathrm{C}$ for another 15 days. $2 \mathrm{~g}$ of the dried samples were placed in $10 \mathrm{ml}$ of concentrated $\mathrm{HNO}_{3}$ at room temperature for one day and then boiled at $180^{\circ} \mathrm{C}$ for one hour. $20 \mathrm{ml}$ of distilled water was added to the solution that was later filtered through a filter paper of $45 \mu \mathrm{m}$. The filtered solutions were analyzed for heavy metal concentrations of $\mathrm{Pb}, \mathrm{Cu}, \mathrm{Ca}, \mathrm{Mg}, \mathrm{Cd}, \mathrm{Cr}, \mathrm{Ni}, \mathrm{Fe}, \mathrm{MN}$, and $\mathrm{Zn}$ using GBC Integra XL-SDS-270 ICP-OES. The range of detection limits (DL) of the device used in the study is: $\mathrm{Pb}>0.377 \mathrm{ppb}, \mathrm{Cu}>0.639 \mathrm{ppb}, \mathrm{Ca}>0.00208$ ppm, $\mathrm{Mg}>0.00758 \mathrm{ppm}, \mathrm{Cd}>0.063 \mathrm{ppb}, \mathrm{Cr}>0.311 \mathrm{ppb}$, $\mathrm{Ni}>0.171 \mathrm{ppb}, \mathrm{Fe}>0.00068 \mathrm{ppm}, \mathrm{Mn}>0.00015 \mathrm{ppm}$, $\mathrm{Zn}>0.00634 \mathrm{ppm}$. The data were analyzed using analysis of variance (ANOVA) and Duncan's Multiple Range Test in SPSS software.

\section{Results and Discussion}

The amount of heavy metal accumulation in each plant species was calculated and the data was analyzed using ANOVA and Duncan's test. Table 1 shows the analysis results.

Given the data in Table 1, there is a statistically significant difference of at least $95 \%$ confidence level between the plant species with respect to all the studied heavy metals other than $\mathrm{Mn}$. The greatest amounts of $\mathrm{Pb}, \mathrm{Cd}$, and $\mathrm{Cr}$ were found in Tilia tomentosa; the greatest amount of $\mathrm{Mn}$ and $\mathrm{Zn}$ in Elaeagnus angustifolia; the greatest amount of $\mathrm{Cu}, \mathrm{Ni}$, and $\mathrm{Fe}$ in Prunus cerasifera; and the greatest amount of $\mathrm{Ca}$ and $\mathrm{Mg}$ in Ailanthus altissima. Table 2 presents the mean value of heavy metal amounts depending on the traffic density and the results of ANOVA and Duncan's test.

As seen in Table 2, there is a statistically significant difference of at least $95 \%$ confidence level in the accumulation of all the studied heavy metals other than $\mathrm{Cu}$ and $\mathrm{Cd}$. The greatest amount of all the heavy metals was found in areas with dense traffic. Table 3 shows the amount of heavy metal accumulation in the studied plant species depending on the traffic density and the results of ANOVA and Duncan's test.

In the areas with dense traffic, the greatest amount of $\mathrm{Cu}, \mathrm{Ni}$, and $\mathrm{Fe}$ was found in Prunus cerasifera, the greatest amount of $\mathrm{Ca}, \mathrm{Mg}$, and $\mathrm{Mn}$ in Ailanthus altissima, the greatest amount of $\mathrm{Cr}$ and $\mathrm{Zn}$ in Elaeagnus angustifolia, and the greatest amount of $\mathrm{Pb}$ and $\mathrm{Cd}$ in Tilia tomentosa. Considering the amount of heavy metal accumulation, Tilia tomentosa significantly differs in $\mathrm{Pb}$ accumulation from other species. The amount of $\mathrm{Pb}$ measured (17.106 ppb) in Tilia tomentosa that grows in areas with less dense traffic is even greater than the amount of $\mathrm{Pb}$ measured in other species growing in areas with dense traffic. The same case is true for the amount of $\mathrm{Cd}$ in Tilia tomentosa, and the amount of $\mathrm{Cu}$ and $\mathrm{Ni}$ in Prunus cerasifera. Another remarkable fact is the great amount of $\mathrm{Cu}$ accumulation in Prunus cerasifera compared to other plant species. The amount of $\mathrm{Cu}$ measured in Prunus cerasifera was $148.253 \mathrm{ppb}$ in the no-traffic areas and $127.593 \mathrm{ppb}$ in the dense-traffic areas. Among the other plant species, Ailanthus altissima is the species with the greatest 
Table 1. Variation of heavy metal amounts depending on plant species.

\begin{tabular}{|c|c|c|c|c|c|}
\hline \multirow{2}{*}{ Metals } & \multicolumn{4}{|c|}{ Species } & \multirow{2}{*}{ F Value } \\
\hline & Tilia tomentosa & Eleagnus angustifolia & Prunus cerasifera & Ailanthus altissima & \\
\hline $\mathrm{Pb}(\mathrm{ppb})$ & $16.322 \mathrm{~b}$ & $8.468 \mathrm{a}$ & $7.511 \mathrm{a}$ & $14.502 \mathrm{~b}$ & $13.733 * * *$ \\
\hline $\mathrm{Cu}(\mathrm{ppb})$ & $32.824 \mathrm{a}$ & $54.764 \mathrm{ab}$ & $169.475 \mathrm{c}$ & $77.806 \mathrm{~b}$ & $44.482 * * *$ \\
\hline $\mathrm{Ca}(\mathrm{ppm})$ & $2.234 \mathrm{ab}$ & $1.532 \mathrm{a}$ & $2.901 \mathrm{~b}$ & $2.892 \mathrm{~b}$ & $4.473 * *$ \\
\hline $\mathrm{Mg}(\mathrm{ppm})$ & $0.380 \mathrm{ab}$ & $0.314 \mathrm{a}$ & $0.585 \mathrm{~b}$ & $0.610 \mathrm{~b}$ & $3.211^{*}$ \\
\hline $\mathrm{Cd}(\mathrm{ppb})$ & $14.780 \mathrm{~b}$ & $5.884 \mathrm{a}$ & $3.957 \mathrm{a}$ & $3.431 \mathrm{a}$ & $10.081 * * *$ \\
\hline $\mathrm{Cr}(\mathrm{ppb})$ & $27.668 \mathrm{~b}$ & $24.360 \mathrm{~b}$ & $16.431 \mathrm{a}$ & $16.504 \mathrm{a}$ & $9.447 * * *$ \\
\hline $\mathrm{Ni}(\mathrm{ppb})$ & $4.571 \mathrm{a}$ & $4.746 \mathrm{a}$ & $13.413 \mathrm{~b}$ & $5.224 \mathrm{a}$ & $8.691 * * *$ \\
\hline $\mathrm{Fe}(\mathrm{ppm})$ & $15.151 \mathrm{bc}$ & $10.813 \mathrm{ab}$ & $16.446 \mathrm{c}$ & $9.368 \mathrm{a}$ & $3.497 *$ \\
\hline $\mathrm{Mn}(\mathrm{ppm})$ & $4.864 \mathrm{a}$ & $7.315 \mathrm{a}$ & $4.824 \mathrm{a}$ & $6.855 \mathrm{a}$ & $1.892 \mathrm{~ns}$ \\
\hline $\mathrm{Zn}(\mathrm{ppm})$ & $5.113 \mathrm{~b}$ & $6.037 \mathrm{~b}$ & $2.386 \mathrm{a}$ & $2.482 \mathrm{a}$ & $9.717 * * *$ \\
\hline
\end{tabular}

*significant at 0.05 level; **significant at 0.01 level; ***significant at 0.001 level; ns not significant. The letters a, b, c, etc. means according to Duncan test results; show that the group is located. It is statistically different from the values contained in different groups, starting with the letter a numerical value grows.

amount of $\mathrm{Cu}(102.660 \mathrm{ppb})$ in the dense-traffic areas. The same is true for Ni accumulation.

Research has shown that heavy metal accumulation differs according to both plant species and traffic density. This result concurs with that of several previous studies. Ozturk and Bozdogan [14] measured heavy metal accumulation in deciduous plants and reported the greatest amount of $\mathrm{Zn}$ accumulation in Betula pendula, that of $\mathrm{Cd}$ accumulation in Elaeagnus angustifolia, that of $\mathrm{Cu}$ accumulation in Catalpa bignonioides, and that of $\mathrm{Ni}$ and Pi in Acer campestre. Similar results have been put forward in many studies [27-28].

Many plants serve as biomonitors of traffic-borne pollutants. Different plant species accumulate different heavy metals at different levels [12, 29]. Distinct parts of a single plant species also accumulate different levels of heavy metals [30-31]. Heavy metal accumulation in plants can also change seasonally [16-19, 32].

According to research results, in dense-traffic areas the greatest amounts of $\mathrm{Cu}, \mathrm{Ni}$, and $\mathrm{Fe}$ were measured in Prunus cerasifera, those of $\mathrm{Ca}, \mathrm{Mg}$, and $\mathrm{Mn}$ in Ailanthus altissima, $\mathrm{Cr}$ and $\mathrm{Zn}$ in Elaeagnus angustifolia, and $\mathrm{Pb}$ and $\mathrm{Cd}$ in Tilia tomentosa. It is an expected fact that heavy metal accumulation differs according to plant species. This result is also supported by previous studies $[14,33]$.

Metals can actually accumulate in plant leaves through foliar transfer after the deposition of

Table 2. Variation of heavy metal amounts depending on traffic density.

\begin{tabular}{|c|c|c|c|c|}
\hline \multirow{2}{*}{ Metals } & \multicolumn{3}{|c|}{ Traffic Density } & \multirow{2}{*}{ F Val } \\
\cline { 2 - 5 } & No & Middle & Dense & $4.979^{*}$ \\
\hline $\mathrm{Pb}(\mathrm{ppb})$ & $8.821 \mathrm{a}$ & $11.523 \mathrm{ab}$ & $14.758 \mathrm{~b}$ & $1.969 \mathrm{~ns}$ \\
\hline $\mathrm{Cu}(\mathrm{ppb})$ & $69.615 \mathrm{a}$ & $71.096 \mathrm{a}$ & $110.441 \mathrm{a}$ & $17.752^{* * *}$ \\
\hline $\mathrm{Ca}(\mathrm{ppm})$ & $1.594 \mathrm{a}$ & $2.186 \mathrm{a}$ & $3.390 \mathrm{~b}$ & $7.095^{* *}$ \\
\hline $\mathrm{Mg}(\mathrm{ppm})$ & $0.322 \mathrm{a}$ & $0.425 \mathrm{a}$ & $0.669 \mathrm{~b}$ & $2.615 \mathrm{~ns}$ \\
\hline $\mathrm{Cd}(\mathrm{ppb})$ & $4.806 \mathrm{a}$ & $5.838 \mathrm{a}$ & $10.395 \mathrm{a}$ & $4.391^{*}$ \\
\hline $\mathrm{Cr}(\mathrm{ppb})$ & $16.595 \mathrm{a}$ & $23.411 \mathrm{~b}$ & $23.716 \mathrm{~b}$ & $5.233^{*}$ \\
\hline $\mathrm{Ni}(\mathrm{ppb})$ & $4.381 \mathrm{a}$ & $5.840 \mathrm{a}$ & $10.745 \mathrm{~b}$ & $27.847^{* * *}$ \\
\hline $\mathrm{Fe}(\mathrm{ppm})$ & $8.361 \mathrm{a}$ & $11.100 \mathrm{a}$ & $19.373 \mathrm{~b}$ & $19.265^{* * *}$ \\
\hline $\mathrm{Mn}(\mathrm{ppm})$ & $4.436 \mathrm{a}$ & $4.465 \mathrm{a}$ & $8.993 \mathrm{~b}$ & $12.721^{* * *}$ \\
\hline $\mathrm{Zn}(\mathrm{ppm})$ & $2.388 \mathrm{a}$ & $3.561 \mathrm{a}$ & $6.065 \mathrm{~b}$ & \\
\hline
\end{tabular}

*significant at 0.05 level; **significant at 0.01 level; ***significant at 0.001 level; ns not significant. The letters a, b, c, etc. means according to Duncan test results; show that the group is located. It is statistically different from the values contained in different groups, starting with the letter a numerical value grows. 
Table 3. Variation of heavy metal amounts depending on plant species and traffic density.

\begin{tabular}{|c|c|c|c|c|c|}
\hline \multirow{2}{*}{ Metals } & \multirow{2}{*}{ Traffic Density } & \multicolumn{4}{|c|}{ Species } \\
\hline & & Tilia tomentosa & Eleagnus angustifolia & Prunus cerasifera & Ailanthus altissima \\
\hline \multirow{4}{*}{$\mathrm{Pb}(\mathrm{ppb})$} & No & $10.920 \mathrm{a}$ & $8.073 \mathrm{a}$ & $3.733 \mathrm{a}$ & $12.560 \mathrm{a}$ \\
\hline & Middle & $17.106 \mathrm{~b}$ & $8.133 \mathrm{a}$ & $5.733 \mathrm{~b}$ & $15.120 \mathrm{a}$ \\
\hline & Dense & $20.940 \mathrm{~b}$ & $9.200 \mathrm{a}$ & $13.066 \mathrm{c}$ & $15.826 \mathrm{a}$ \\
\hline & F Val & $15.407 * *$ & $0.267 \mathrm{~ns}$ & $146.175 * * *$ & $2.465 \mathrm{~ns}$ \\
\hline \multirow{4}{*}{$\mathrm{Cu}(\mathrm{ppb})$} & No & $28.726 \mathrm{a}$ & $48.280 \mathrm{a}$ & $148.253 \mathrm{~b}$ & $53.200 \mathrm{a}$ \\
\hline & Middle & $29.046 \mathrm{a}$ & $50.186 \mathrm{a}$ & $127.593 \mathrm{a}$ & $77.560 \mathrm{~b}$ \\
\hline & Dense & $40.700 \mathrm{~b}$ & $65.826 \mathrm{~b}$ & $232.580 \mathrm{c}$ & $102.660 \mathrm{c}$ \\
\hline & F Val & $6.303 *$ & $179.310 * * *$ & $600.178 * * *$ & $236.980 * * *$ \\
\hline \multirow{4}{*}{$\mathrm{Ca}(\mathrm{ppm})$} & No & $1.068 \mathrm{a}$ & $1.044 \mathrm{a}$ & $2.628 \mathrm{~b}$ & $1.638 \mathrm{a}$ \\
\hline & Middle & $2.040 \mathrm{~b}$ & $1.760 \mathrm{~b}$ & $2.554 \mathrm{a}$ & $2.389 \mathrm{~b}$ \\
\hline & Dense & $3.594 \mathrm{c}$ & $1.794 \mathrm{c}$ & $3.522 \mathrm{c}$ & $4.650 \mathrm{c}$ \\
\hline & F Val & $3835.959 * * *$ & $1996.499 * * *$ & $6691.754 * * *$ & $67168.692 * * *$ \\
\hline \multirow{4}{*}{$\mathrm{Mg}(\mathrm{ppm})$} & No & $0.373 \mathrm{a}$ & $0.178 \mathrm{a}$ & $0.586 \mathrm{~b}$ & $0.153 \mathrm{a}$ \\
\hline & Middle & $0.377 \mathrm{a}$ & $0.320 \mathrm{~b}$ & $0.533 \mathrm{a}$ & $0.459 \mathrm{~b}$ \\
\hline & Dense & $0.390 \mathrm{a}$ & $0.445 \mathrm{c}$ & $0.636 \mathrm{c}$ & $1.219 \mathrm{c}$ \\
\hline & F Val & $0.619 \mathrm{~ns}$ & $32.578 * *$ & $37.235 * * *$ & $1741.304 * * *$ \\
\hline \multirow{4}{*}{$\mathrm{Cd}(\mathrm{ppb})$} & No & $11.800 \mathrm{a}$ & $1.553 \mathrm{a}$ & $2.353 \mathrm{a}$ & $3.120 \mathrm{a}$ \\
\hline & Middle & $12.200 \mathrm{a}$ & $5.820 \mathrm{ab}$ & $2.433 \mathrm{a}$ & $3.300 \mathrm{a}$ \\
\hline & Dense & $20.340 \mathrm{a}$ & $10.280 \mathrm{~b}$ & $7.086 \mathrm{~b}$ & $3.873 \mathrm{a}$ \\
\hline & F Val & $0.926 \mathrm{~ns}$ & $9.272 \%$ & $15.844 * *$ & $1.168 \mathrm{~ns}$ \\
\hline \multirow{4}{*}{$\mathrm{Cr}(\mathrm{ppb})$} & No & $23.546 \mathrm{a}$ & $20.246 \mathrm{a}$ & $10.566 \mathrm{a}$ & $12.020 \mathrm{a}$ \\
\hline & Middle & $34.860 \mathrm{a}$ & $28.213 \mathrm{a}$ & $14.800 \mathrm{~b}$ & $15.773 \mathrm{~b}$ \\
\hline & Dense & $24.600 \mathrm{a}$ & $24.620 \mathrm{a}$ & $23.926 \mathrm{c}$ & $21.720 \mathrm{c}$ \\
\hline & F Val & $4.356 \mathrm{~ns}$ & $4.943 \mathrm{~ns}$ & $149.530 * * *$ & $115.651 * * *$ \\
\hline \multirow{4}{*}{$\mathrm{Ni}(\mathrm{ppb})$} & No & $3.553 \mathrm{a}$ & $2.953 \mathrm{a}$ & $8.046 \mathrm{a}$ & $2.973 \mathrm{a}$ \\
\hline & Middle & $6.280 \mathrm{~b}$ & $3.380 \mathrm{a}$ & $8.846 \mathrm{a}$ & $4.853 \mathrm{a}$ \\
\hline & Dense & $3.880 \mathrm{a}$ & $7.906 \mathrm{~b}$ & $23.346 \mathrm{~b}$ & $7.846 \mathrm{a}$ \\
\hline & F Val & $5.648 *$ & $67.524 * * *$ & $58.816 * * *$ & $2.796 \mathrm{~ns}$ \\
\hline \multirow{4}{*}{$\mathrm{Fe}(\mathrm{ppm})$} & No & $8.373 \mathrm{a}$ & $6.480 \mathrm{a}$ & $13.346 \mathrm{~b}$ & $5.246 \mathrm{a}$ \\
\hline & Middle & $17.373 \mathrm{~b}$ & $8.626 \mathrm{~b}$ & $10.493 \mathrm{a}$ & $7.906 \mathrm{~b}$ \\
\hline & Dense & $19.706 \mathrm{c}$ & $17.333 \mathrm{c}$ & $25.500 \mathrm{c}$ & $14.953 \mathrm{c}$ \\
\hline & F Val & $2024.707 * * *$ & $6539.155 * * *$ & $4256.958 * * *$ & $1650.333 * * *$ \\
\hline \multirow{4}{*}{$\mathrm{Mn}(\mathrm{ppm})$} & No & $2.560 \mathrm{a}$ & $5.713 \mathrm{a}$ & $4.813 \mathrm{~b}$ & $4.660 \mathrm{~b}$ \\
\hline & Middle & $5.960 \mathrm{~b}$ & $5.513 \mathrm{a}$ & $3.440 \mathrm{a}$ & $2.946 \mathrm{a}$ \\
\hline & Dense & $6.073 \mathrm{~b}$ & $10.720 \mathrm{~b}$ & $6.220 \mathrm{c}$ & $12.960 \mathrm{c}$ \\
\hline & F Val & $226.863 * * *$ & $2025.624 * * *$ & $1196.541 * * *$ & $7934.586 * * *$ \\
\hline
\end{tabular}


Table 3. Continued.

\begin{tabular}{|c|c|c|c|c|c|}
\hline \multirow{4}{*}{ Zn (ppm) } & No & $2.773 \mathrm{a}$ & $3.560 \mathrm{a}$ & $1,813 \mathrm{a}$ & $1.406 \mathrm{a}$ \\
\cline { 2 - 6 } & Middle & $5.246 \mathrm{~b}$ & $5.300 \mathrm{~b}$ & $1.853 \mathrm{a}$ & $1.846 \mathrm{~b}$ \\
\cline { 2 - 6 } & Dense & $7.320 \mathrm{c}$ & $9.253 \mathrm{c}$ & $3.493 \mathrm{~b}$ & $4.193 \mathrm{c}$ \\
\cline { 2 - 6 } & F Val & $\mathbf{3 5 7 . 9 7 6 * * *}$ & $\mathbf{1 7 2 0 . 1 8 9 * * *}$ & $\mathbf{1 6 9 . 4 7 5 * * *}$ & $\mathbf{2 4 7 . 5 3 6 * * *}$ \\
\hline
\end{tabular}

*significant at 0.05 level; **significant at 0.01 level; ***significant at 0.001 level; ns not significant. The letters a, b, c, etc. means according to Duncan test results; show that the group is located. It is statistically different from the values contained in different groups, starting with the letter a numerical value grows.

atmospheric particles on leaf surfaces [34]. As stomata in plant leaves regulate the entry of $\mathrm{CO}_{2}$ and water vapor into plants, they show the maximum potential for the detection of heavy metal accumulation in leaves [35]. The size and density of stomata are significantly influenced by environmental conditions. Additionally, there is an inverse proportion between the size and number of stomata [36-38]. Among the plant species studied in this paper, Tilia tomentosa and Prunus cerasifera have similar stomata sizes; however, the stomatal opening is larger and the number of stomata is greater in Tilia tomentosa $[5,7,39]$.

Leaf anatomy can be a significant factor affecting particle deposition. For example, a small leaf area and a high amount of structural wax (conifers) have been suggested to increase particle deposition on leaf surfaces [40]. Considering the leaf features of the studied plant species, there is a significant difference between their leaf surfaces. Elaeagnus angustifolia has the smallest leaf surface and Ailanthus altissima has a fairly small leaf surface compared to the larger leaf surfaces of Prunus cerasifera and Tilia tomentosa. However, leaf anatomy can be a more effective factor than leaf surface with respect to heavy metal accumulation. Kacar et al. [41] suggest that some plant leaves are thicker and thus make less use of light, which has a significant effect on plant metabolism. In a similar vein, Zeren et al. [42] reported a considerable difference in leaf chlorophyll content and measured the amount of chlorophyll in Prunus ceracifera, Ailantus altissima, Tilia tomentosa, and Elaeagnus angustifolia as $12.68 \mathrm{cc}, 18.58 \mathrm{cc}, 35.16$ cc, and $75.50 \mathrm{cc}$, respectively. Among the studies plant species, Elaeagnus angustifolia is considerably different from others in terms of both chlorophyll content and leaf thickness.

Heavy metal accumulation in plants is probably associated with their anatomical and physiological features. Heavy metal accumulation on leaf surfaces occurs through stomata, cuticular cracks, lenticels, ectodesmata, and aqueous pores. Heavy metals absorption occurs through ectodesmata between subsidiary cells and guard cells in the cuticular membrane or epidermal cell wall [10]. Shahid et al. [10] note that heavy metal accumulation varies according to the structure of plant canopy, leaf inclination angle, branch density, leaf lamina morphologic anatomical structure, and leaf area. Plants' anatomical and morphological characteristics are influenced by the mutual interaction of genetic and environmental conditions [43]. Thus, there are great differences between species [26]. Likewise, there can also be great differences in the anatomical and morphological structure of subspecies, varieties, forms, and even origins of the same species. Accordingly, these differences cause plants to react differently to external factors [44-46]. This situation is related to plants' genetic structure. A similar situation is inevitably possible for plants' heavy metal accumulation capacity. Thus, in addition to plant species, genetic structure and age seem to affect heavy metal accumulation. Shahid et al. [10] highlight that young leaves accumulate more metal compared to old leaves as their epidermis is less thick.

Another factor affecting anatomical and morphological characteristics is growing conditions, which significantly affect a plant's response to stress factors [47-53]. Environmental conditions also cause significant changes to anatomical and physiological structures. For example, there can be a 2-3-fold difference in the chlorophyll content of leaves growing in shaded conditions and those growing in intense light [5-7, 18-19, 46, 54]. Similar results have been demonstrated for other factors. The structure and density of stomata - among the major factors determining a plant's potential for heavy metal accumulation - can be affected by several environmental factors [55], including drought stress [56-57], light [47-48], and salt stress [5859]. Air pollution has also been reported to be among the major factors affecting the structure and density of stomata [54].

The prevention and reduction of environmental pollution have now risen to prominence with the growing importance of the quality of urban living. Green spaces are vital constituents of urban ecosystems and thus serve as major devices for reducing airborne pollution and increasing the quality of life. There are various pollutants (industrial, domestic, traffic, etc.) in and around cities. Urban roads that qualify as open green spaces are areas where air pollution is high. Pollutant gases in the air occur 5 to 25 times more and dust condensation and particles occur 10 times more in urban compared to rural areas [14, 39, 60-63]. Trafficrelated air pollution has increased in developing cities in Turkey with the gradually growing number of vehicles 
participating in urban traffic in and around the cities [64]. This situation negatively affects the quality of the environment and illustrates the importance of urban vegetation.

Research on determining air pollution in the city has shown that air pollution varies depending on many factors such as traffic density, climate change, wind direction, and precipitation [7, 39, 60-63, 65-66]. Thus, heavy metal concentration in the air can also vary depending on many parameters. Accordingly, it is of great importance to monitor this variation and to use plants effectively in order to reduce heavy metal concentrations.

\section{Conclusions}

Plants' visual qualities are generally foregrounded in the selection of plants used in urban centers, while their functions are neglected. However, the first thing to do for the functional and effective use of plants is to determine which plants best serve the desired function before selecting plant species accordingly.

The present study has indicated that, compared to the other plant spices, Tilia tomentosa is more effective in accumulating $\mathrm{Pb}$ and $\mathrm{Cd}$ and Prunus cerasifera is more effective in accumulating $\mathrm{Cu}$ and $\mathrm{Ni}$. The use of these species in spaces where these heavy metals pose a problem will lead to a more effective outcome in reducing the amount of heavy metals in the air.

Today, air pollution in urban centers is one of the greatest problems of cities. Thus, future similar studies need to be carried out to determine the most effective species in the removal of heavy metals from the air. Future research should address plant organs (besides plant species) that absorb heavy metals more, and plant species that most accumulate heavy metals depending on weather conditions.

\section{References}

1. KAYA L.G., CETIN M., DOYGUN H. A holistic approach in analyzing the landscape potential: Porsuk Dam Lake and its environs, Turkey. Fresen. Environ. Bull. 18 (8), 1525, 2009.

2. CETIN M., TOPAY M., KAYA L.G., YILMAZ B. Efficiency of bioclimatic comfort in landscape planning process: case of Kutahya. Turkish Journal of Forestry 1 (1), 83, 2010.

3. CETIN M. Consideration of permeable pavement in landscape architecture. J. Environ. Protect. Ecol. 16 (1), $385,2015$.

4. CETIN M. Determining the bioclimatic comfort in Kastamonu City. Environ. Monit. Assess. 187 (10), 640, 2015. DOI: $10.1007 / \mathrm{s} 10661-015-4861-3$

5. CETIN M. Changes in the amount of chlorophyll in some plants of landscape studies. Kastamonu University Journal of Forestry Faculty, 16 (1), 239, 2016.

6. CETIN M. A Change in the Amount of $\mathrm{CO}_{2}$ at the Center of the Examination Halls: Case Study of Turkey. Studies on
Ethno-Medicine, 10 (2), 146, 2016.

7. CETIN M. Change in Amount of Chlorophyll in Some Interior Ornamental Plants, Kastamonu University Journal of Engineering and Sciences 3 (1), 11, 2017.

8. ISINKARALAR O., ISINKARALAR K., EKIZLER A., ILKDOGAN C. Changes in the Amounts of $\mathrm{CO}_{2}$ and Particulate Matter in Kastamonu Province Depending on Weather Conditions and Locations, Journal of Chemical, Biological and Physical Sciences, 7 (3), 643, 2017.

9. EL-HASAN T., AL-OMARI H., JIRIES A., AL-NASIR F. Cyprees tree (Cupressus semervirens L.) bark as an indicator for heavy metal pollution in the atmosphere of Amman City, Jordan. Environ. Int. 28 (6), 513, 2002

10. SHAHID M., DUMAT C., KHALID S., SCHRECK E., XIONG T., NIAZI N. K. Foliar heavy metal uptake, toxicity and detoxification in plants: A comparison of foliar and root metal uptake. J. Hazard. Mater. 325, 36, 2017.

11. TOMASEVIC, M., ANICIC, M. Trace element content in urban tree leaves and SEM-EDAX characterization of deposited particles. Physics, Chemistry and Technology, 8 (1), 1, 2010.

12. PETROVA S., YURUKOVA L., VELCHEVA I. Possibilities of using deciduous tree species in trace element biomonitoring in an urban area (Plovdiv, Bulgaria). Atmos. Pollut. Res. 5 (2), 196, 2014.

13. OZEL H. B., OZEL H. U., VAROL T. Using Leaves of Oriental Plane (Platanus orientalis L.) to Determine the Effects of Heavy Metal Pollution Caused by Vehicles. Pol. J. Environ. Stud. 24 (6), $2569,2015$.

14. OZTURK S., BOZDOGAN E. The Contribution of Urban Road Trees on Improving The Air Quality in an Urban Area, Fresen. Environ. Bull. 24 (5A), 1822, 2015.

15. CETIN M., SEVIK H. Evaluating the recreation potential of Ilgaz Mountain National Park in Turkey. Environ. Monit. Assess. 188 (1), 52, 1, 2016.

16. CETIN M. Using GIS analysis to assess urban green space in terms of accessibility: case study in Kutahya. Int. J. Sust. Dev. World. 22 (5), 420, 2015.

17. CETIN M. Evaluation of the sustainable tourism potential of a protected area for landscape planning: a case study of the ancient city of Pompeipolis in Kastamonu. Int. J. Sust. Dev. World. 22 (6), 490, 2015. DOI: 10.1080/135045 09.2015.1081651,2015.

18. CETIN M. Determination of bioclimatic comfort areas in landscape planning: A case study of Cide Coastline. Turkish Journal of Agriculture-Food Science and Technology 4 (9), 800, 2016.

19. CETIN M. Sustainability of urban coastal area management: A case study on Cide. J. Sustainable For. 35 (7), 527, 2016.

20. YIGIT N., SEVIK H., CETIN M. KAYA N. Determination of the Effect of Drought Stress on the Seed Germination in Some Plant Species, Water Stress in Plants, ISBN:978-95351-2621-8, Chapter 3, 43, InTech, August, 2016.

21. CETIN M., SEVIK H. Measuring the Impact of Selected Plants on Indoor $\mathrm{CO}_{2}$ Concentrations. Pol. J. Environ. Stud. 25 (3), 973, 2016.

22. SEVIK H., CETIN M. Effects of Water Stress on Seed Germination for Select Landscape Plants, Pol. J. Environ. Stud. 24 (2), 689, 2015.

23. CETIN M., ADIGUZEL F., KAYA O., SAHAP A. Mapping of bioclimatic comfort for potential planning using GIS in Aydin. Environment, Development and Sustainability, 20 (1), 361-375, 2018. https://doi.org/10.1007/s10668-016-9885-5 
24. CETIN M., SEVIK H. Change of air quality in Kastamonu city in terms of particulate matter and $\mathrm{CO}_{2}$ amount. Oxid. Commun. 39 (4-II), 3394, 2016.

25. KAYA L.G. Assessing Forests and Lands with Carbon Storage and Sequestration Amount by Trees in the State of Delaware USA. Scientific Research and Essays, 10 (4), $1100,2009$.

26. BROOKS R.M., CETIN M. Determination of the influence of pavement friction on the initial velocity using the accident reconstruction engineering principles. International Journal of Engineering Inventions, 2 (6), 63, 2013.

27. LI S. N., KONG L. W., LU S. W., CHEN B., GAO C., SHI Y. Beijing common green tree leaves' accumulation capacity for heavy metals. Huan jing ke xue $=$ Huanjing kexue, 35 (5), 1891, 2014.

28. SRIVASTAVA S., AGRAWAL S. B., MONDAL M. $\mathrm{K}$. A review on progress of heavy metal removal using adsorbents of microbial and plant origin. Environ. Sci. Pollut. Res. 22 (20), 15386, 2015.

29. ANICIC M., SPASIC T., TOMASEVIC M., RAJSIC S., TASIC M. Trace elements accumulation and temporal trends in leaves of urban deciduous trees (Aesculus hippocastanum and Tilia ssp.). Ecol. Indic. 11 (3), 824, 2011.

30. TOŠIĆ S., ALAGIĆ S., DIMITRIJEVIĆ M., PAVLOVIĆ A., NUJKIĆ M. Plant parts of the apple tree (Malus spp.) as possible indicators of heavy metal pollution. Ambio, $\mathbf{4 5}$ (4), 501, 2016.

31. YABANLI M., YOZUKMAZ A., SEL F. Heavy metal accumulation in the leaves, stem and root of the invasive submerged macrophyte Myriophyllum spicatum L.(Haloragaceae): an example of Kadin Creek (Mugla, Turkey). Braz. Arch. Biol. Technol. 57 (3), 434, 2014.

32. BŘEZINOVÁ T., VYMAZAL J. Evaluation of heavy metals seasonal accumulation in Phalaris arundinacea in a constructed treatment wetland. Ecol. Eng., 79, 94, 2015.

33. HU Y., WANG D., WEI L., ZHANG X., SONG B. Bioaccumulation of heavy metals in plant leaves from Yan' an city of the Loess Plateau, China. Ecotoxicol. Environ. Saf. 110, 82, 2014

34. XIONG T.T., LEVEQUE T., AUSTRUY A., GOIX S., SCHRECK E., DAPPE V., SOBANSKA S., FOUCAULT Y., DUMAT C. Foliar uptake and metal (loid) bioaccessibility invegetables exposed to particulate matter, Environ. Geochem. Health 36 (5), 897, 2014.

35. XU Z., ZHOU G. Responses of leaf stomatal density to water status and its relationship with photosynthesis in a grass. J. Exp. Bot. 59 (12), 3317, 2008.

36. GALMÉS J., FLEXAS J., SAVÉ R., MEDRANO H. Water relations and stomatal characteristics of Mediterranean plants with different growth forms and leaf habits: responses to water stress and recovery. Plant and Soil, 290 (1-2), 139, 2007.

37. HETHERINGTON A.M., WOODWARD F.I. The role of stomata in sensing and driving environmental change. Nature 424 (6951), 901, 2003.

38. PEARCE D. W., MILLARD S., BRAY D.F., ROOD S. B. Stomatal characteristics of riparian poplar species in a semi-arid environment. Tree Physiol. 26 (2), 211, 2006.

39. CETIN M., MOSSI M.M.M., AKBUDAK K.Y. Visual Examination of Natural and Cultural Landscape Values in Kastamonu City Center for Sustainable Spatial Development. Ecology, Planning and Design. Chapter
35. Eds: Irina Koleva, Ulku Duman Yuksel, Lahcen Benaabidate, St. Kliment Ohridski University Press, ISBN: 978-954-07-4270-0, 465, 2017.

40. RÄSÄNEN J. V., HOLOPAINEN T., JOUTSENSAARI J., NDAM C., PASANEN P., RINNAN Å., KIVIMÄENPÄÄ M. Effects of species-specific leaf characteristics and reduced water availability on fine particle capture efficiency of trees. Environ. Pollut. 183, 64, 2013.

41. KACAR B., KATKAT V., OZTURK S. Light, plant physiology. The Nobel Broadcast Distribution, Ankara, 270, 2010 [In Turkish]

42. ZEREN I., CANTURK U., YASAR M. O. Change of Chlorophyll Quantity in Some Landscaping Plants, Journal of Bartin Faculty of Forestry, 19 (2), 2, 2017.

43. SEVIK H., YAHYAOGLU Z., TURNA I. Determination of Genetic Variation Between Populations of Abies nordmanniana subsp. bornmulleriana Mattf According to some Seed Characteristics, Genetic Diversity in Plants, ISBN 978-953-51-0185-7, Chapter 12, 231, InTech, March, 2012.

44. TURKYILMAZ A., SEVIK H., CETIN M. The use of perennial needles as biomonitors for recently accumulated heavy metals. Landscape and Ecological Engineering, 14 (1), 115-120, 2017. https://link.springer.com/article/10.1007 \%2Fs11355-017-0335-9

45. TURKYILMAZ A., SEVIK H., CETIN M. The use of perennial needles as biomonitors for recently accumulated heavy metals. Landscape and Ecological Engineering, 2017 [In Press] DOI: 10.1007/s11355-017-0335-9

46. SEVIK H., CETIN M., KAPUCU O., ARICAK B., CANTURK U. Effects of light on morphologic and stomatal characteristics of Turkish Fir needles (Abies nordmanniana subsp. Bornmulleriana Mattf.). Fresen. Environ. Bull. 26 (11), 6579, 2017.

47. SEVIK H., CETIN M., KAPUCU O. Effect of Light on Young Structures of Turkish Fir (Abies nordmanniana subsp. bornmulleriana). Oxid. Commun. 39 (1-II), 485, 2016.

48. CETIN M. Landscape Engineering, Protecting Soil, and Runoff Storm Water. Chapter 27, in book: InTech-Open Science-Open Minds, Book: Advances in Landscape Architecture-Environmental Sciences, Eds: Murat Ozyavuz, ISBN 978-953-51-1167-2, Online July 1 $1^{\text {st }}, 697$, 2013.

49. TOPACOGLU O., SEVIK H., AKKUZU E. 2016. Effects of Water Stress on Germination of Pinus nigra Arnold. Seeds, Pak. J. Bot. 48 (2), 447, 2016.

50. GUNEY K., CETIN M., GUNEY K.B., MELEKOGLU A. The Effects of Some Hormones Applications on Lilium martagon L. Germination and Morpholgical Characters. Pol. J. Environ. Stud. 26 (6), 2533-2538, 2017. DOI: 10.15244/pjoes/70895, http://www.pjoes.com/pdf/26.6/ Pol.J.Environ.Stud.Vol.26.No.6.2533-2538.pdf

51. GUNEY K., CETIN M., GUNEY K.B., MELEKOGLU A. The Effects of Some Hormones Applications on Lilium martagon L. Germination and Morpholgical Characters. Pol. J. Environ. Stud. 26 (6), 1-6, [In Press], 2017. http:// www.pjoes.com/doi/70895.pdf

52. SEVIK H., CETIN M. Effects of some hormone applications on germination and morphological characters of endangered plant species Lilium artvinense L. Onion scales. Bulg. Chem. Commun. 48 (2), 259, 2016.

53. SEVIK H., CETIN M. Evaluation of Topiary Applications and Problems: A Case Study of Kastamonu, International Journal of Multidisciplinary Thought, 05 (05), 45, 2016. 
54. SEVIK H., CETIN M., ARICAK B. The variable of leaf micromorphogical characters on grown in distinct climate conditions in some landscape plants. International Journal of Arts \& Sciences' (IJAS) International Conference for Physical, Life and Health Sciences, Las Vegas, Nevada, USA. 13 to 17 March 2017, 2017.

55. BANON S., FERNANDEZ J.A., FRANCO J.A., TORRECILLAS A., ALARCÓN J.J., SÁNCHEZBLANCO M.J. Effects of water stress and night temperature preconditioning on water relations and morphological and anatomical changes of Lotus creticus plants. Sci. Hort. 101 (3), 333, 2004.

56. YANG H., WANG G. Leaf stomatal densities and distribution in Triticum aestivum under drought and $\mathrm{CO}_{2}$ enrichment. Acta Phytoecologica Sinica 25 (3), 312, 2001.

57. LIU S., LIU J., CAO J., BAI C., SHI R. Stomatal distribution and character analysis of leaf epidermis of jujube under drought stress. Journal of Anhui Agricultural Science 34, 1315, 2006.

58. ZHAO R. X., ZHANG Q. B., WU X. Y., WANG Y. The effects of drought on epidermal cells and stomatal density of wheat leaves. Inner Mongolia Agricultural Science and Technology 6, 6, 2001.

59. ROMERO-ARANDA R., SORIA T., CUARTERO J. Tomato plant-water uptake and plant-water relationships under saline growth conditions. Plant Science, 160 (2), 265, 2001.

60. CETIN M., SEVIK H., ISINKARALAR K. Changes in the Particulate Matter and $\mathrm{CO}_{2}$ Concentrations Based on the
Time and Weather Conditions: The Case of Kastamonu. Oxid. Commun. 40 (1-II), 477, 2017.

61. CETIN M., SEVIK H., SAAT A. Indoor air quality: The samples of Safranbolu Bulak Mencilis Cave. Fresen. Environ. Bull. 26 (10), 59650, 2017.

62. CETIN M., MOSSI M.M.M., AHMAIDA E.A., SEVIK $\mathrm{H}$. The exchanging of leaf micromorphological characters in Pyracantha coccinea depends on traffic intensity. The 3rd International Symposium on EuroAsian Biodiversity, 05-08 July, 2017, Minsk, Belarus.

63. CETIN M., AHMAIDA E.A., MOSSI M.M.M., SEVIK $\mathrm{H}$. The effect of the amount of $\mathrm{CO}_{2}$ on Sansevieria trifasciata in indoor environment. The $3^{\text {rd }}$ International Symposium on EuroAsian Biodiversity, 05-08 July, 2017, Minsk, Belarus.

64. ERDOGAN E., YAZGAN E.M. Landscaping to Reduce Traffic Noise Problem in Cities: Ankara Case, Journal of Tekirdag Agricultural Faculty, 4 (2), 201, 2007.

65. CAKIR G., MUDERRISOGLU H., KAYA L.G. Assessing the Effects of Long Term Recreational Activities on Landscape Changes in Abant Natural Park Turkey. The Journal of Forestry Research, 27 (2), 453, 2016.

66. SEVIK H., AHMAIDA, E.A., CETIN M. Change of the Air Quality in the Urban Open and Green Spaces: Kastamonu Sample. Ecology, Planning and Design. Chapter 31. Eds: Irina Koleva, Ulku Duman Yuksel, Lahcen Benaabidate, St. Kliment Ohridski University Press, ISBN: 978-954-074270-0, 409, 2017. 